\title{
In Silico Design, Synthesis and In Vitro Antidiabetic Activity of Novel 5-Furyl- 1,3,4-Thiadiazolimines
}

\author{
Sherin A. Hameed ${ }^{1 *}$, Joyamma Varkey ${ }^{2}$, P Jayasekhar ${ }^{3}$ \\ ${ }^{1}$ College of Pharmaceutical Sciences, Government Medical College, Thiruvananthapuram, Kerala \\ ${ }^{2}$ College of Pharmaceutical Sciences, Government Medical College, Alappuzha. \\ ${ }^{3}$ College of Pharmacy, National University of Science and Technology, Sultanate of Oman \\ Email:- sherinirshad@gmail.com
}

\begin{abstract}
Postprandial hyperglycemia plays an important role in the development of T2DM. The promising therapeutic approach is to decrease hyperglycemia by decreasing the postprandial rise in blood glucose concentration. In our study, a series of novel 5-furyl- 1,3,4-thiadiazol-2-imine derivatives were designed and those with good Physico-chemical properties were synthesized by oxidative cyclization between aryl acid and thiosemicarbazide using phosphorous oxychloride and subsequent treatment with aromatic aldehydes with varying substituents. Docking studies with the human pancreatic alpha-amylase enzyme in complex with myricetin (PDB ID: 4GQR) and peroxisome proliferator-activated receptor gamma (PPARgamma) (PDB ID: 1FM6) were done to predict the protein-ligand binding modes. The compounds SA07, SA03 and SA04 showed significantly high docking scores while SA01, SA05 and SA06 showed moderate scores. All derivatives were subjected to in vitro anti-diabetic screening using chromogenic dinitro salicylic acid method ( $\alpha$ amylase inhibition assay). Significant percentages of inhibition were reported for SA03, SA07 and SA04 with acarbose as standard. Molecular docking revealed that synthesized derivatives and target proteins were actively involved in binding before and after systemic absorption and had a significant correlation with their biological activity.
\end{abstract}

KEYWORDS: $1,3,4$-thiadiazole, docking, $\alpha$ - amylase, anti-diabetic

\section{INTRODUCTION}

Diabetes mellitus (DM) is a group of metabolic diseases in which there are high blood sugar levels or hyperglycemia over a prolonged period. DM is one of the prime concerns of morbidity and mortality around the globe with an expected projection of 366 million cases in 2030 compared to 171 million in 2000 [1]. It is ranked seventh among the leading causes of death and is considered third when its fatal complications are taken into account [2]. India was declared as the "diabetes capital of the world" by WHO in 2013. DM is a condition in which the pancreas no longer produce enough insulin or cells stop responding to insulin that is produced so that the glucose in the blood cannot be absorbed in to the cells of the body [3]. Between two types of diabetes, type 2 is more prevalent than type 1, with more than $90 \%$ of the total diabetic patients suffering from it. Postprandial hyperglycemia plays an important role in the development of T2DM [4]. The promising therapeutic approach is to decrease hyperglycaemia by decreasing the postprandial rise in blood glucose concentration. This is achieved by retarding the digestion and absorption of ingested carbohydrates through the inhibition of carbohydrate hydrolysing enzymes such as $\alpha$-amylase and $\alpha$-glucosidase [5]. Currently, experimental T2DM drug discovery is focused on compounds with insulin-sensitizing activity that acts via several mechanisms.

1,3, 4-thiadiazole, a five membered ring system containing sulphur and nitrogen atom have become a considerable class of heterocycles and a great area for researchers because of their wide range of biological activity. Versatile biological activities of this moiety is probably due to strong aromaticity of the ring system, which provide good in vivo stability and least toxicities for higher vertebrates, including humans. When different functional groups are attached to thiadiazole nucleus, it may interact with biological receptors and produce an outstanding property [6]. Literature survey revealed that 1,3,4-thiadiazole and its derivatives possesses wide range of therapeutic activities like antimicrobial [7], antifungal [8], antitubercular [9], [10], anti-inflammatory [11], wound healing, diuretic [12], antiulcer, antidiabetic [13], anticonvulsant [14], anticancer [15], anti-leshmanial, antidepressant, antioxidant, radio-protective, and antiviral activities [16]. Thiadiazole moiety acts as a "hydrogen binding domain" and "two-electron donor system". They occur in four isomeric form viz., 1,2,3-thiadiazole, 1,2,4-thiadiazole, 1,2,5-thiadiazole, 1,3,4-thiadiazole [17], [18]. 
<smiles>c1csnn1</smiles>

1,2,3-thiadiazole<smiles>c1cnsn1</smiles>

1,2,5-thiadiazole<smiles>c1ncsn1</smiles>

1,2,4-thiadiazole<smiles>c1nncs1</smiles>

\section{1,3,4-thiadiazole}

In silico approaches are being used today in drug discovery to assess the ADMET properties of compounds at the early stages of discovery and development. ACD Lab Chemsketch, PASS (Prediction of Activity Spectra for Substances), Osiris property calculator, Pre-ADMET prediction, Molinspiration and SwissADME are some of the software which helps pharmaceutical scientists to select the best candidates for development as well as to reject those with a low probability of success [19]. The three-dimensional structure of a protein or protein-ligand complex is helpful in lead identification using molecular modeling. Discovery studio, AUTODOCK, Glide, and SwissDOCK are some of the software providing docking analysis. Discovery Studio is a suite of software for simulating small molecule and macromolecule systems. It is developed and distributed by Dassault Systemes BIOVIA (formerly Accelrys) [20].

Our present study includes the in silico screening of a series of 5-furyl-1,3,4-thiadiazole-2-imine compounds, their docking studies with targets like the human pancreatic alpha-amylase enzyme in complex with myricetin (PDB ID: 4GQR), peroxisome proliferator-activated receptor gamma (PPARgamma) (PDB ID: 1FM6) and in vitro screening for anti-diabetic activity by $\alpha$-amylase inhibition assay.

\section{EXPERIMENTAL METHODS}

The in silico modeling of all proposed compounds were carried out by using Molinspiration (21), ACDLAB Chemsketch (22), Pre ADMET, Osiris property calculator (24), and PASS (Prediction of Activity Spectra for Substances) (25) to predict the physiological and biological parameters.

All the chemicals used for synthesis were of laboratory reagent grade and were obtained from Sigma-Aldrich and S.D. fine chemicals Ltd. Melting points were determined in open capillaries in the electrical melting point apparatus and are uncorrected. Analytical thin-layer chromatography was performed on precoated silica gel plates (Merck) to establish the identity of reactants and products monitored in-between reactions as well as at the end for completion of the reaction. The spots were visualized by iodine vapours in an enclosed chamber. Infra-Red spectra of compounds were recorded on 1) Perkin Elmer Spectrum Two FT-IR spectrometer in the range of 4000$200 \mathrm{~cm}-1$. Proton $(1 \mathrm{H})$ Nuclear Magnetic Resonance Spectra of compounds were recorded on Bruker Advance II 400 NMR Spectrophotometer using DMSO solvent.

\section{Synthesis of selected derivatives}

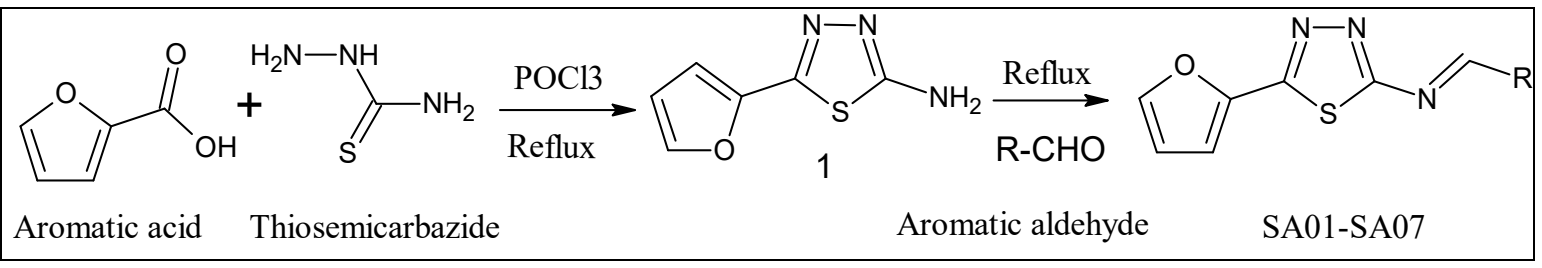

Fig 1: Scheme for the synthesis

Step 1 Synthesis of 2-amino-5 furyl-1,3,4-thiadiazole [26].

An equimolar amount of mixture of 2 -furoic acid $(0.1$ mole $)$ and thiosemicarbazide $(0.1$ mole $)$, in $\mathrm{POCl}_{3}$ (excess), was heated for half an hour, water $(90 \mathrm{ml})$ added and reaction mixture refluxed till the completion of reaction (TLC), cooled to room temperature, poured to ice-cold water, neutralized with saturated $\mathrm{KOH}$ solution, and recrystallized from $95 \%$ ethanol.

Step 2 Synthesis of 5-furyl-1,3,4-thiadiazol-2-imine derivatives (SA01-SA07) [27].

To the compound $1(0.01 \mathrm{M})$ in $20 \mathrm{ml}$ ethanol, selected aldehyde $(0.01 \mathrm{M})$ in $15 \mathrm{ml}$ ethanol was added and refluxed for 5-6hr. The volume of resultant solution was reduced to half by distillation under reduced pressure. The resulting solution was poured on crushed ice and kept overnight below $20^{\circ} \mathrm{c}$ for crystallization. The solid which got separated was dried and recrystallized from ethanol.

\section{Molecular docking}

Docking Analysis was performed using docking software Discovery studio 2018 for identifying the binding affinity of proposed compounds with two targets by Library docking method

The human pancreatic alpha amylase enzyme in complex with myricetin with PDB id: 4GQR were retrieved from Protein Data Bank (PDB) with a resolution of $1.2 \mathrm{~A}^{0}[28]$. The protein consists of a single polypeptide chain with sequence length of 496 amino acids. The binding sites of protein interaction with its native ligand are Trp 
59, Gln63, Asp197 and Glu233. Docking analysis were performed by selecting binding site from receptor cavities in the target protein using charmm/charmm36 as force field.

The crystal structure of the heterodimer of the human retinoid X receptor alpha and peroxisome proliferatoractivated receptors gamma (PPARgamma) ligand binding domains respectively bound with 9-cis retinoic acid and rosiglitazone and co-activator peptides were retrieved from PDB with PDB ID: 1FM6 with a resolution of $2.1 \mathrm{~A}^{0}$. The active site selected for the studies are Phe 282, Cys285, Ser289, Leu330, Met364, His449, Tyr473, the binding site of rosiglitazone.

\section{In vitro anti-diabetic activity ( $\alpha$-Amylase Inhibition assay) [29].}

Porcine pancreatic $\alpha$ amylase (PPA) was used for the preliminary screening of $\alpha$ amylase inhibitors from the compounds using the chromogenic dinitro salicylic acid (DNSA) method. A total of $500 \mu \mathrm{L}$ of $0.02 \mathrm{M}$ sodium phosphate buffer ( $\mathrm{pH} 6.9$ with $0.006 \mathrm{M} \mathrm{NaCl}$ ) containing $20 \mathrm{mg} / \mathrm{mL}$ of $\alpha$ - amylase and varying concentration $(25$, $50,75, \& 100 \mu \mathrm{g} / \mathrm{ml}$ ) of extract as inhibitor were pre-incubated at $25^{\circ} \mathrm{C}$ for $10 \mathrm{~min}$. After the pre-incubation, 500 $\mu \mathrm{L}$ of a $1 \%$ starch solution in $0.02 \mathrm{M}$ sodium phosphate buffer $(\mathrm{pH} 6.9)$ was added to each tube at timed intervals. The reaction was stopped using $1.0 \mathrm{~mL}$ of DNSA colour reagent. The test tubes were incubated for $5 \mathrm{~min}$, cooled., diluted by adding $10 \mathrm{ml}$ distilled water and the absorbance was measured at 540 $\mathrm{nm}$. Varying concentrations of acarbose $(1 \mathrm{mg} / \mathrm{ml}$ stock) were treated as standard.

$\%$ of inhibition $=\frac{\mathrm{B}-\mathrm{A} * 100}{(\mathrm{~B}-\mathrm{C})}$

A- OD of test sample

B- OD of blank with starch and alpha amylase

C- OD of Control with starch only,

\section{RESULTS AND DISCUSSION}

Seven 1,3,4- thiadiazole derivatives were screened for best physico-chemical parameters using different software. All derivatives were screened for RO5 compliance using Chemsketch and Molinspiration software and were found to obey Lipinski's rule of 5 (RO5). The results were detailed in Table 1. Molecular parameters of proposed derivatives were further evaluated using Ghose filter and Viber filter. Ghose filter rule stated that compounds with Partition coefficient $\log \mathrm{P}$ in $(-0.4$ to +5.6$)$ range, Molar refractivity from 40 to 130 , Molecular weight from 180 to 480 and Number of atoms from 20 to 70 (includes H-bond donors [e.g. OHs and NHs] and H-bond acceptors [e.g. Ns and Os]) give more druglikeness character. While Veber rule stated that for a compound predicted to have good oral bioavailability then the rotatable bond count should be less than or equal to 10 and polar surface area should be less than or equal to 140. All the proposed derivatives obeyed the Ghose and Veber filter rules.

All the proposed derivatives have TPSA value less than140 angstroms. This parameter is significant to correlate proposed derivatives with the human intestinal absorption, Caco-2 monolayer's permeability, and blood brain barrier penetration. Percentage of absorption ( $\%$ ABS) was estimated using the equation: \% ABS $=109-(0.345 \times$ TPSA $)$, according to Zhao et al. ADME parameters were shown in Table 2.

Seven derivatives were synthesized conventionally and their structures were confirmed by IR and 1H-NMR spectra. The details of different substitution, melting point, \% yield and spectral details were given in Table 3 .

Docking studies were performed with human pancreatic alpha amylase enzyme (4GQR) to find out alpha amylase inhibiting activity and with peroxisome proliferator-activated receptor gamma (PPARgamma) (1FM6) to find out the antidiabetic activity after systemic absorption. Docking analysis report as shown in Table 4 revealed that except SA02 all others have good interaction with the binding site of human pancreatic alpha amylase enzyme. The compounds SA07, SA03 and SA04 showed good docking score while SA01, SA05 and SA06 moderate score. Docking with PPARgamma showed that compound SA07 and SA04 have maximum docking score.

In vitro anti-diabetic screening results as given in Table 5 showed maximum percentage of inhibition for SA03and SA07 which have maximum docking score also. Thus in vitro anti-diabetic analytical report compliments docking analysis results. Percentage of inhibition shown by various derivatives were compared with standard acarbose, shown in figure 5.

Both in vitro and docking studies showed that SA02, (Z)- $N$-[5-(furan-2-yl)-1,3,4-thiadiazol-2-yl]-1phenylmethanimine which is a derivative with unsubstituted phenyl ring attached to imine linkage have least docking score. SA03 which is chemically (Z)-1-(2,4-dichlorophenyl)- $N$-[5-(furan-2-yl)-1,3,4-thiadiazol-2-yl] methanimine and SA07, (E)-1-(furan-2-yl)- $N$-[5-(furan-2-yl)-1,3,4-thiadiazol-2-yl] methanimine; both exhibited maximum docking score with alpha amylase as well as good percentage of inhibition. Presence of electron donating groups at $2^{\text {nd }}$ and $4^{\text {th }}$ position of phenyl ring contributed more to get strong receptor interaction. Highly aromatic furyl ring also give much hydrogen bonding interaction with the receptor resulting significant alpha amylase inhibitory action. 
Table 1: Evaluation of RO5 with Molinspiration and Chemsketch software.

\begin{tabular}{|lcccccccccc|}
\hline Code & Molecular formula & MiLog P & nHAc & nHDo & Volume & $\begin{array}{c}\text { M.Ref } \\
\mathbf{C m}^{3}\end{array}$ & $\begin{array}{c}\text { nrot } \\
\text { b }\end{array}$ & TPSA & $\begin{array}{c}\text { Mol.Wt } \\
\text { No: of } \\
\text { atoms }\end{array}$ \\
\hline SA01 & C15H14N4OS & 3.35 & 5 & 0 & 259.99 & 85.97 & 4 & 54.53 & 298.36 & 35 \\
\hline SA02 & C13H9N3OS & 3.25 & 4 & 0 & 214.09 & 73.17 & 3 & 51.29 & 255.30 & 27 \\
\hline SA03 & C13H7C12N3OS & 4.53 & 4 & 0 & 241.16 & 82.37 & 3 & 51.29 & 324.19 & 27 \\
\hline SA04 & C16H15N3O4S & 2.88 & 7 & 0 & 290.73 & 90.61 & 6 & 78.99 & 345.37 & 39 \\
\hline SA05 & C13H9N3O2S & 3.19 & 5 & 1 & 222.11 & 74.02 & 3 & 71.52 & 271.29 & 28 \\
\hline SA06 & C13H8N4O3S & 3.18 & 7 & 0 & 237.42 & 78.83 & 4 & 97.11 & 300.29 & 29 \\
\hline SA07 & C11H7N3O2S & 2.50 & 5 & 0 & 195.66 & 65.34 & 3 & 64.43 & 245.26 & 24 \\
\hline
\end{tabular}

Table 2: ADME parameters calculated by Pre-ADMET software.

\begin{tabular}{|llllllll|}
\hline Code & BBB & Caco2 & HIA & MDCK & PPB & SP & \%ABS \\
\hline SA01 & 1.21 & 36.53 & 99.12 & 20.81 & 91.86 & -3.47 & 90.19 \\
\hline SA02 & 1.56 & 31.50 & 98.76 & 239.22 & 95.86 & -3.42 & 91.30 \\
\hline SA03 & 2.91 & 54.97 & 98.45 & 72.59 & 100 & -3.39 & 91.30 \\
\hline SA04 & 0.42 & 27.17 & 96.99 & 2.93 & 93.68 & -3.94 & 81.75 \\
\hline SA05 & 0.81 & 10.17 & 95.57 & 78.68 & 98.00 & -3.66 & 84.33 \\
\hline SA06 & 0.11 & 1.54 & 88.09 & 2.04 & 90.64 & -3.52 & 75.50 \\
\hline SA07 & 0.68 & 29.95 & 95.2 & 209.74 & 86.9 & -3.69 & 86.77 \\
\hline
\end{tabular}

Table 3: Physico-spectral details of synthesised compounds

\begin{tabular}{|c|c|c|c|c|c|}
\hline \multirow[b]{2}{*}{ Code } & \multirow[b]{2}{*}{$-\mathbf{R}$} & \multirow[b]{2}{*}{$\begin{array}{c}\mathbf{m p} \\
{ }^{\circ} \mathbf{c}\end{array}$} & \multirow[b]{2}{*}{$\begin{array}{c}\% \\
\text { yield }\end{array}$} & \multicolumn{2}{|c|}{ Spectral analysis } \\
\hline & & & & $\begin{array}{l}\text { IR spectral details } \\
\text { Peaks at } \mathbf{n m}\end{array}$ & $\begin{array}{l}\text { Nmr spectral details } \\
\text { chemical shifts at ( } 400 \\
\text { MHz,DMSO \& ppm) }\end{array}$ \\
\hline SA01 & $\begin{array}{l}\text { 4-N,N-dimethyl } \\
\text { phenyl }\end{array}$ & 201 & 62 & $\begin{array}{l}3104(\mathrm{Ar}-\mathrm{C}-\mathrm{H}), 2919 \quad(\mathrm{C}-\mathrm{H}), \\
1635 \quad(\mathrm{~N}=\mathrm{CH}), \quad 1521 \quad(\mathrm{C}=\mathrm{C}), \\
1268\left(\mathrm{C}-\mathrm{N}, \mathrm{N}\left(\mathrm{CH}_{3}\right)_{2}, 883(\mathrm{~N}-\mathrm{N}),\right. \\
688(\mathrm{C}-\mathrm{S}-\mathrm{C})\end{array}$ & $\begin{array}{l}2.93\left(\mathrm{~s}, 6 \mathrm{H}, \mathrm{CH}_{3}\right), 6.6-7.8( \\
7 \mathrm{H}, \quad \mathrm{Ar}-\mathrm{H}), 8.87 \quad(\mathrm{~s}, \quad 1 \mathrm{H}, \\
\mathrm{N}=\mathrm{CH}),\end{array}$ \\
\hline SA02 & -phenyl & 236 & 65 & $\begin{array}{l}3015(\text { Ar-C-H }), \quad 2923(\mathrm{C}-\mathrm{H}) \\
1635(\mathrm{~N}=\mathrm{CH}), 1503(\mathrm{C}=\mathrm{C}), 1103 \\
(\mathrm{C}-\mathrm{H}, \text { Furan }), 883(\mathrm{~N}-\mathrm{N}), 684(\mathrm{C}- \\
\text { S-C) }\end{array}$ & $\begin{array}{l}6.7-8.3(\mathrm{~m}, 8 \mathrm{H}, \mathrm{Ar}-\mathrm{H}) 8.99(\mathrm{~s}, \\
1 \mathrm{H}, \mathrm{N}=\mathrm{CH})\end{array}$ \\
\hline SA03 & $\begin{array}{c}2,4- \\
\text { dichorophenyl }\end{array}$ & 220 & 57 & $\begin{array}{l}3022(\mathrm{Ar}-\mathrm{C}-\mathrm{H}), 2917 \quad(\mathrm{C}-\mathrm{H}), \\
1518(\mathrm{C}=\mathrm{C}), 1630(\mathrm{~N}=\mathrm{CH}), 888 \\
(\mathrm{~N}-\mathrm{N}), 692(\mathrm{C}-\mathrm{S}-\mathrm{C})\end{array}$ & $\begin{array}{l}6.7-7.9(\mathrm{~s}, 6 \mathrm{H}, \mathrm{Ar}-\mathrm{H}), 9.0(\mathrm{~s}, \\
1 \mathrm{H}, \mathrm{N}=\mathrm{CH})\end{array}$ \\
\hline SA04 & $\begin{array}{l}\text { 3,4,5- } \\
\text { trimethoxyphenyl }\end{array}$ & 208 & 48 & 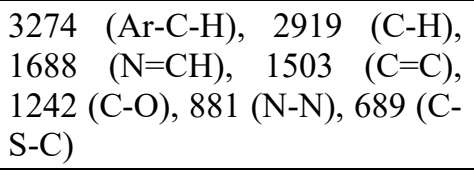 & $\begin{array}{l}3.7-3.9\left(\mathrm{~s} 9 \mathrm{H}, \quad \mathrm{CH}_{3}\right), 6.8-7.7 \\
(\mathrm{~m}, 5 \mathrm{H}, \text { Ar-H }), 8.9(\mathrm{~s}, 1 \mathrm{H}, \\
\mathrm{N}=\mathrm{CH})\end{array}$ \\
\hline SA05 & 2-hyroxyphenyl & 192 & 55 & $\begin{array}{l}3682(\mathrm{OH}), 3134(\mathrm{Ar}-\mathrm{C}-\mathrm{H}) \\
(\mathrm{C}-\mathrm{H}), 1605 \quad(\mathrm{~N}=\mathrm{CH}), \quad 1500 \\
(\mathrm{C}=\mathrm{C}), 888(\mathrm{~N}-\mathrm{N}), 688(\mathrm{C}-\mathrm{S}-\mathrm{C})\end{array}$ & $\begin{array}{l}6.7-8.0(\mathrm{~m}, 7 \mathrm{H}, \mathrm{Ar}-\mathrm{H}), 8.9(\mathrm{~s}, \\
1 \mathrm{H}, \mathrm{N}=\mathrm{CH})\end{array}$ \\
\hline SA06 & 3-nitrophenyl & 185 & 60 & $\begin{array}{l}3115(\mathrm{Ar}-\mathrm{C}-\mathrm{H}), 2924(\mathrm{C}-\mathrm{H}), \\
1613(\mathrm{~N}=\mathrm{CH}), 1530\left(\mathrm{Ar}-\mathrm{NO}_{2}\right), \\
889(\mathrm{~N}-\mathrm{N}), 690(\mathrm{C}-\mathrm{S}-\mathrm{C})\end{array}$ & $\begin{array}{l}6.7-8.7(\mathrm{~m}, 7 \mathrm{H}, \mathrm{Ar}-\mathrm{H}), \quad 8.7(\mathrm{~s}, \\
1 \mathrm{H}, \mathrm{N}=\mathrm{CH})\end{array}$ \\
\hline SA07 & 2-furyl & 251 & 43 & $\begin{array}{l}3130(\text { Ar-C-H }) 2916 \quad(\mathrm{C}-\mathrm{H}) \\
1630(\mathrm{~N}=\mathrm{CH}), 1495(\mathrm{C}=\mathrm{C}), 887 \\
(\mathrm{~N}-\mathrm{N}), 686(\mathrm{C}-\mathrm{S}-\mathrm{C})\end{array}$ & $\begin{array}{l}6.5-7.9(\mathrm{~m}, 6 \mathrm{H}, \mathrm{Ar}-\mathrm{H}), 8.82 \\
(\mathrm{~s}, 1 \mathrm{H}, \mathrm{N}=\mathrm{CH})\end{array}$ \\
\hline
\end{tabular}


Table 4: Docking analysis report with human pancreatic alpha amylase enzyme (4GQR) and peroxisome proliferator-activated receptor gamma (PPARgamma) (1FM6)

\begin{tabular}{|llllll|}
\hline SL:No. & Ligand & $\begin{array}{l}\text { Docking } \\
\text { score }\end{array}$ & $\begin{array}{l}\text { Interacting Residue } \\
\text { 4GQR }\end{array}$ & $\begin{array}{l}\text { Docking } \\
\text { score }\end{array}$ & $\begin{array}{l}\text { Interacting } \\
\text { Residue(1FM6) }\end{array}$ \\
\hline 1 & SA01 & 54.5996 & $\begin{array}{l}\text { Trp59, Asp197, Glu233 } \\
\text { (3WHB) }\end{array}$ & 81.12 & $\begin{array}{l}\text { Met364,Ser289, } \\
\text { Arg288,His323 }\end{array}$ \\
\hline 2 & SA02 & 50.9353 & No H bond interaction & 71.42 & Met364, Ser289 \\
\hline 3 & SA03 & $\mathbf{6 4 . 7 5 1 7}$ & Ala198, A:His201, Ala198 & 76.15 & Met364, ser289 \\
\hline 4 & SA04 & $\mathbf{6 3 . 3 9 8 6}$ & $\begin{array}{l}\text { Trp59, Asp197, Asp197, } \\
\text { Glu233 }\end{array}$ & $\mathbf{9 4 . 5 4}$ & $\begin{array}{l}\text { Gln286,Ser289, } \\
\text { Arg288,Phe282 (Whb) }\end{array}$ \\
\hline 5 & SA05 & 54.1312 & Asp197 & 73.68 & Met364,Ser289 \\
\hline 6 & SA06 & 59.1726 & His201 & 87.49 & Tyr473, Gln286 \\
\hline 7 & SA07 & $\mathbf{6 8 . 0 2 5}$ & Trp59 whb & $\mathbf{9 5 . 5 0}$ & His449, Ser289 \\
\hline
\end{tabular}

Table 5: Report of in vitro antidiabetic screening.

\begin{tabular}{|lllllllll|}
\hline \multirow{2}{*}{$\boldsymbol{\mu l} / \mathbf{m l}$} & \multicolumn{7}{c|}{$\%$ of inhibition(Each value expressed as Mean \pm SEM) } \\
\cline { 2 - 9 } & Acarbose & SA01 & SA02 & SA03 & SA04 & SA05 & SA06 & SA07 \\
\hline 25 & 24.35 & $40.46 \pm 3.65$ & $29.09 \pm 2.56$ & $69.09 \pm 3.89$ & $35.52 \pm 1.17$ & $12.4 \pm 1.483$ & $37.45 \pm 2.73$ & $83.64 \pm 2.34$ \\
\hline 50 & 48.71 & $47.15 \pm 0.85$ & $37.4 \pm 3.93$ & $85.45 \pm 3.22$ & $42.47 \pm 1.61$ & $30.15 \pm 4.47$ & $39.79 \pm 2.06$ & $87.27 \pm 2.23$ \\
\hline 75 & 76.92 & $51.83 \pm 4.09$ & $46.82 \pm 2.27$ & $90.91 \pm 2.46$ & $64.09 \pm 1.94$ & $47.61 \pm 2.58$ & $41.13 \pm 1.93$ & $89.09 \pm 2.87$ \\
\hline 100 & 93.58 & $54.18 \pm 4.61$ & $53.5 \pm 1.89$ & $94.55 \pm 1.80$ & $76.44 \pm 0.98$ & $56.34 \pm 2.56$ & $45.15 \pm 1.24$ & $92.73 \pm 1.53$ \\
\hline
\end{tabular}

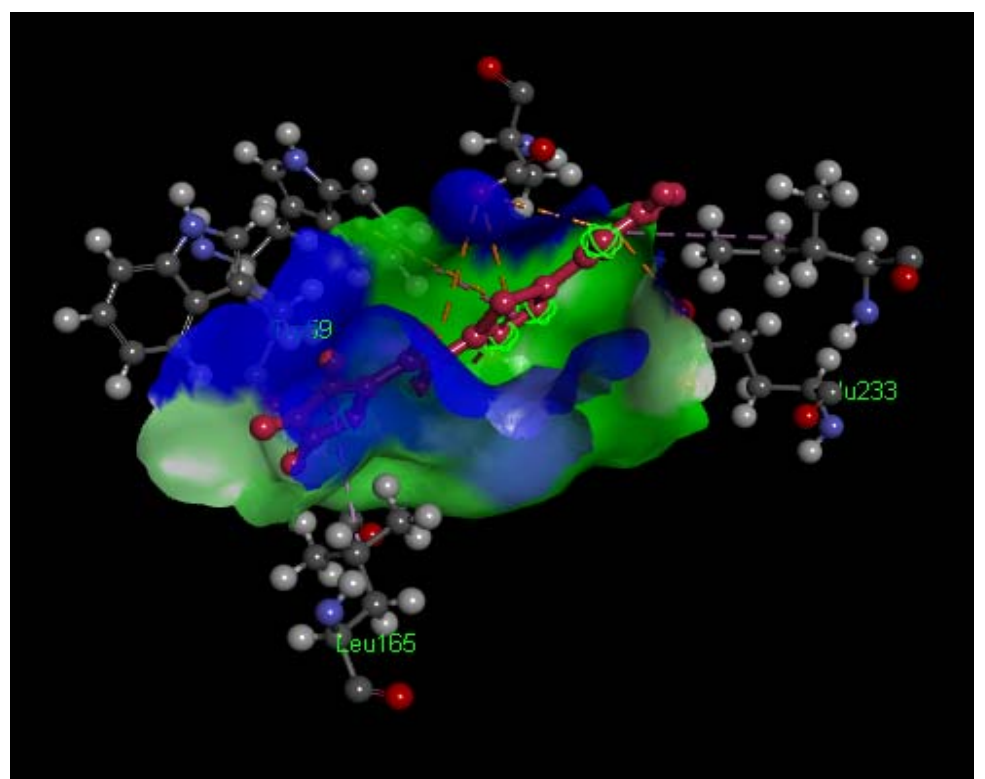

Fig 1: 3D view 


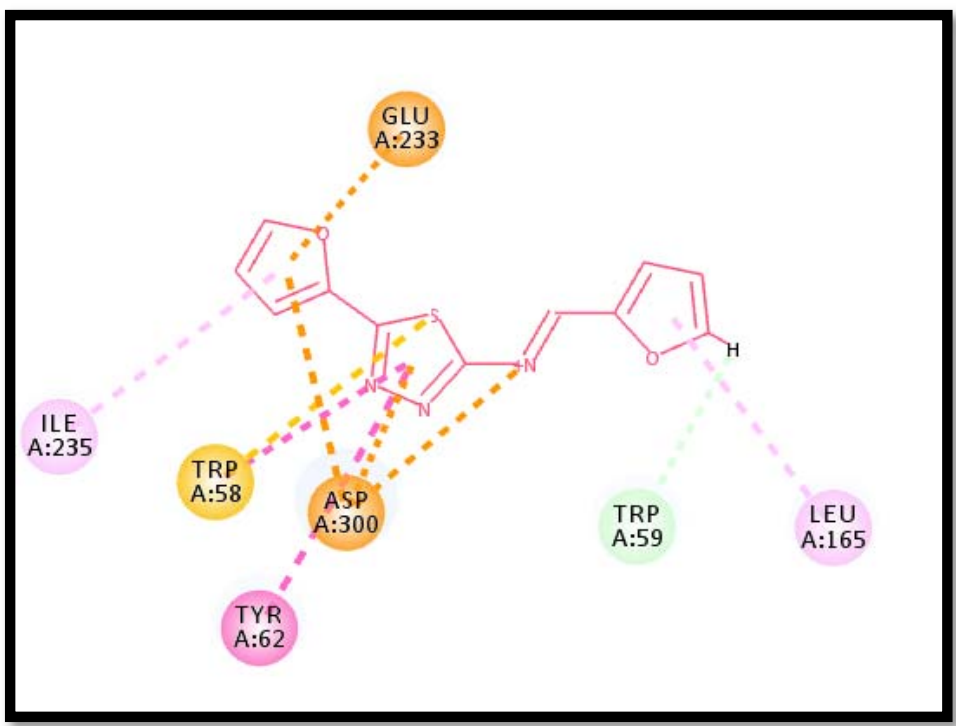

Fig 2: 2D view

Interaction of SA07 which have maximum docking score with $4 \mathrm{GQR}$ were shown in figure 1 and 2

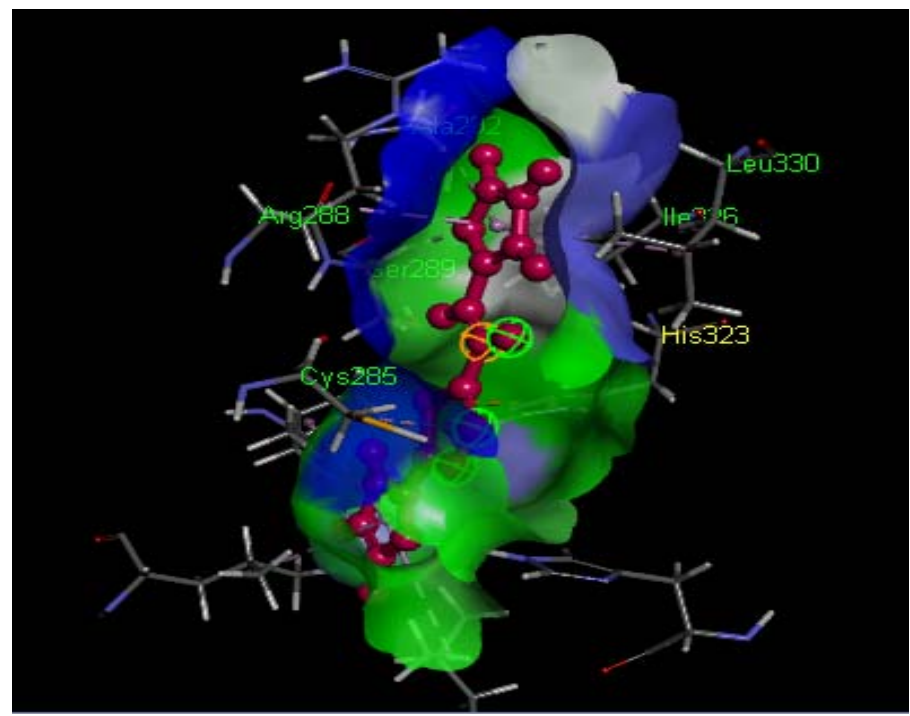

Fig 3: 3D view

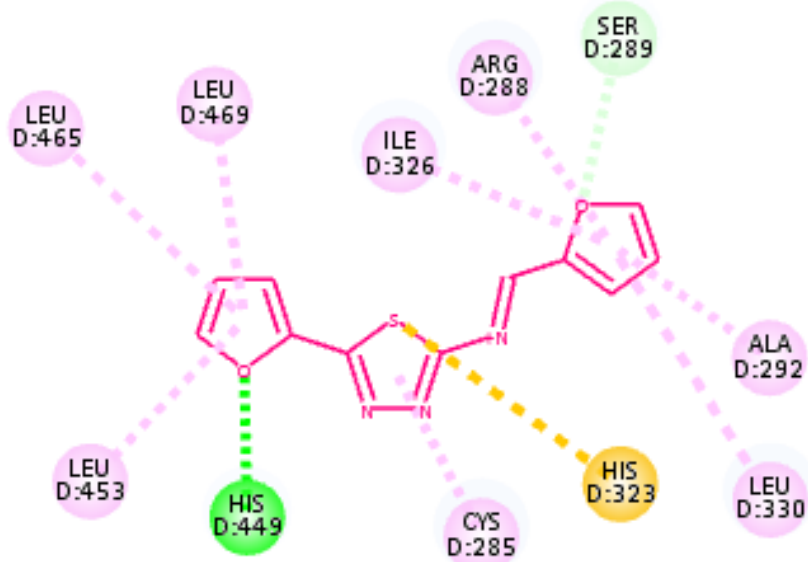

Fig 4: 2D view 
Interaction of SA07 which have maximum docking score with 1FM6 were shown in figure 3 and 4

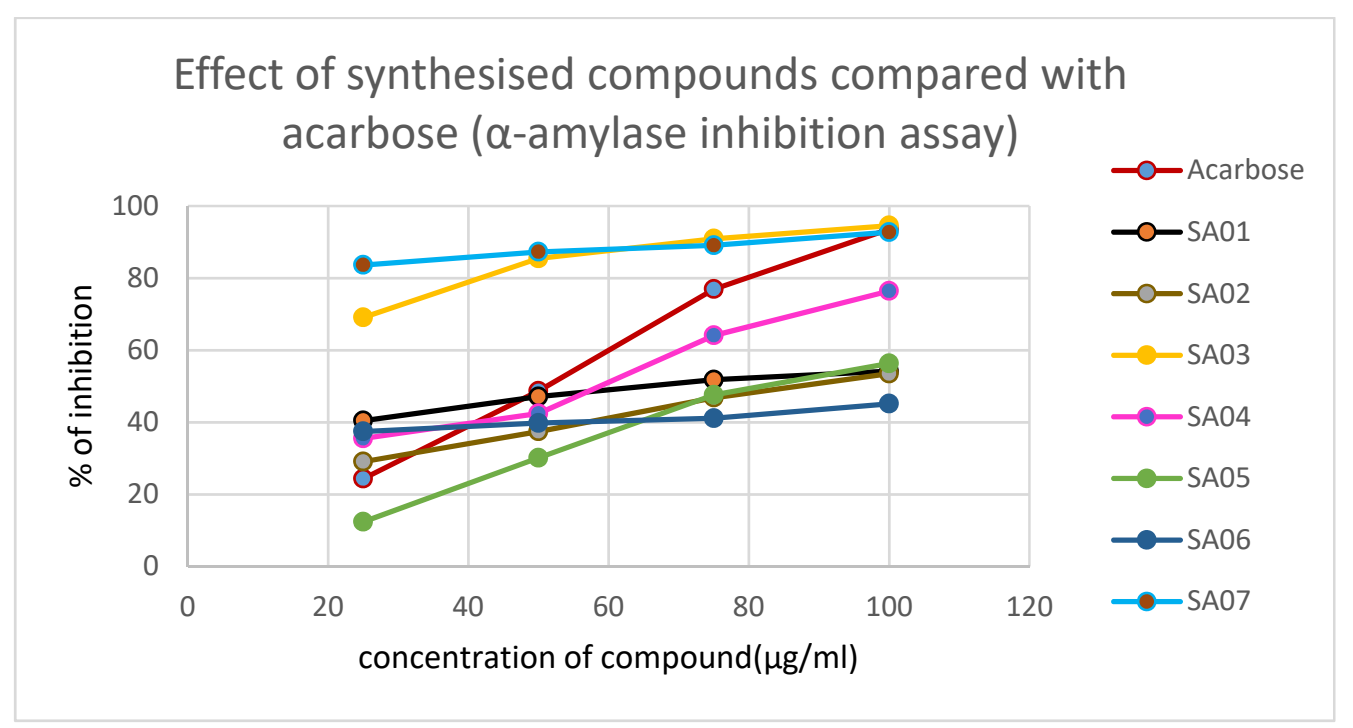

Figure 5: Comparison of percentage of inhibition shown by synthesised compounds.

\section{CONCLUSION}

The designed and synthesized 5-furyl-1,3,4-thiadiazol-2-imine derivatives showed good docking score and in vitro anti-diabetic activity. In silico physico chemical prediction studies confirmed that the majority of the title compounds possessed the druglikeness character. In vitro screening results suggested that compounds in which phenyl ring with electron donating groups at 2, 4th position (SA03) and that with furyl ring (SA07) attached to imine linkage exhibited significant alpha-amylase inhibitory activity. The docking studies with PPAR gamma receptor proved that the proposed compound SA07 and SA04 have best docking score, thus giving insight to antidiabetic activity after systemic absorption also. Compounds namely SA03, SA07 and SA04 having significant docking score and percentage of inhibition, can be selected for further optimisation and can be explored for in vivo activity in the mere future thus resulting in the development of novel anti-diabetic drugs with better pharmacological profile.

\section{CONFLICT OF INTERESTS:}

The authors declare that there is no conflict of interests regarding the publication of this paper.

\section{ACKNOWLEDGEMENT}

The authors are thankful to the authorities of all software used in this study for providing free access and also to Department of Computational Biology \& Bioinformatics, University of Kerala, Karyavattom for performing Docking Analysis. Grateful to The Central Laboratory for Instrumentation and Facilitation (CLIF) at Kariavattom, University of Kerala for spectral analysis.

\section{REFERENCES}

[1] Wild S, Roglic G, Green A, Sicree A, King H. Global prevalence of diabetes: Estimates for the year 2000 and projections for 2030. Diabetes Care. 2004; 27(5): 1047-1053.

[2] Vidhya, Renitta. Evaluation of antihyperglycemic and antihyperlipidemic activities of an edible gastropod (Achatina fulica) in alloxaninduced diabetic mice. Asian J Pharm Clin Res. 2016; 9(3]): 206-211.

[3] Pattan SR, Kekare P, Dighe NS, Nirmal SA, Musmade DS, Parjane SK, et al. Synthesis and biological evaluation of some 1, 3, 4thiadiazoles. J. Chem. Pharm. Res. 2009; 1(1): 191-198.

[4] Baron AD. Postprandial hyperglycaemia and $\alpha$-glucosidase inhibitors. Diabetes Res Clin Pract. 1998; 40 (1): S51-S55.

[5] Sindhu. SN, Kavrekar V, Mishra A. In vitro studies on alpha amylase and alpha glucosidase inhibitory activities of selected plant extracts. Euro. J. Exp. Bio. 2013; 3(1):128-132.

[6] Visagaperumal D, Ramalingam J, Chandy V. 1, 3, 4-Thiadiazoles: An Overview. Curr Res Bioorg Org Chem. 2018; 103. DOI: 10.29011/CRBOC -101. 100003

[7] Serban G, Stanasel O, Eugenia S, Bota S. 2-Amino-1,3,4-thiadiazole as a potential scaffold for promising antimicrobial agents. Drug Des. Dev. Ther. 2018; 12: 1545-66.

[8] Shrivastava K, Purohit S, Singhal S. Studies On Nitrogen and Sulphur Containing Heterocyclic Compound: 1,3,4 - thiadiazole. Asian J Biomed Pharmaceut Sci 2013; 3(21): 6-23.

[9] Karigar AA, Himaja M, Malisunil V, Jagadeesh PK. One Pot Synthesis and Antitubercular Activity of 2-Amino-5-Aryl-5H-Thiazolo (4,3-B) 1,3,4- Thiadiazoles. IRJP. 2011; 2(1): 153-158.

[10] Syed MA, YRP Reddy, Chandrasekhar KB. Design, one pot synthesis and biological evaluation of imidazo[2,1-b] [1,3,4]-thiadiazole derivatives for their antitubercular and antifungal activity. J of Applied Pharm.Sci. 2018; 8(07): 021-027.

[11] Kamal M, Shakya AK, Jawaid T. 1,3,4-thiadiazole as antiinflammatory agent: a review. IJCRR.2001; 2(11): 14-26.

[12] Banerjee R, Roy D, Banerjee M. Synthesis, wound healing and diuretic activity of some new 1, 3, 4 thiadiazole derivatives. WJPPS.2015; 4(11): 1769-1778.

[13] Datar PA, Deokule TA. Design and synthesis of thiadiazole derivatives as antidiabetic agents. Med chem. 2014; 4: 390-399. 
[14] Raj V, Rai A, Singh M, Kumar R, Kumar A, Kumar S, and Sharma SK. Recent update on 1,3,4-thiadiazole derivatives: as anticonvulsant agents. ARJPM. 2015; 1(1): 34-61.

[15] Malleshappa NN, Patel HM, Singh N, Gadad AK, Cameotra SS and Badiger A. Synthesis and anticancer evaluation of novel 2-cyclo propyl imidazo[2,1-b]1,3,4-thiadiazole derivatives. Eur J of Med Chem. 2011; 49(9): 4411-18.

[16] Sherin AH, Joyamma V, Jayasekhar P. Schiff bases and Bicyclic derivatives comprising 1, 3, 4-thiadiazole moiety- A Review on their Pharmacological activities. Asian J. Pharm. Res. 2019; 9(4): 299-306.

[17] Gadhiya B, Rajput M, Atul B, Kartik L. Design, synthesis and evaluation of antimicrobial activities of some novel thiazole and thiadiazole derivatives clubbed with 1Hbenzimidazole.RASAYAN. J.CHEM. 2016; 9(3): 355-372.

[18] Rakesh Y, Divya Y, Sarvesh KP. Novel biphenyl imidazo[2,1- b][1,3,4]-thiadiazole -a versatile scaffold. DHR-IJPS. 2012; 2(1): 20-37.

[19] Bibi S, Sakata. K Current Status of Computer-Aided Drug Design for Type 2 Diabetes. Curr Comput Aided Drug. 2016; 12: 167-177.

[20] Oprea TI. Virtual Screening in Lead Discovery: A Viewpoint. Molecules. 2002; 7: 51-62.

[21] Rajasekhar KK. Abdrrahman SS, Mekonnen YT, Padmavathamma M, Ranganayakulu D, Shankarananth V. In silico prediction of biological activity, selected pharmacokinetic and toxicity profile of some 2,4,6-trisubstituted pyrimidines derived from guanabenz and guanfacine. IJIPR. 2015; 6(2): 468-477.

[22] ACD labs Chem sketch. ver 12.0 for Windows, Advanced Chemistry Development Inc, Toronto, Canada, http://www.acdlabs.com.

[23] Ravi KK. Giri A, Nadendla RR. In silico Adme Profiling of Cdk9 Inhibitors. J Sci Res Pharm. 2018;7(3):30-34.

[24] "Osiris Property Explorer.": 〈http://www.organic-chemistry.org/ prog/peo/

[25] "PASS (Prediction of Activity Spectra for Substances) program"., http://www.way2drug.com/passonline.

[26] Atta KFM, Omaima OM, Farahat, Alaa ZA, Ahmed, Marei MG, Synthesis and antibacterial activities of novel imidazo[2,1-b]-1,3,4thiadiazoles. Molecules. 2011;16: 5496-5506.

[27] Pandey A, Rajavel R, Chandraker S, Deepak D. Synthesis of schiff bases of 2-amino-5-aryl-1,3,4- thiadiazole and its analgesic, antiinflammatory and anti-bacterial activity. J Chem. 2012; 9(4): 2524-2531.

[28] Ganesan MS, Raja KK, Narasimhan K, Murugesan S, Karan KB. Design, synthesis, a-amylase inhibition and in silico docking study of novel quinoline bearing proline derivatives. J. Mol. Struct. 2020; 1208: 127873.

[29] Merlin NJ, Sandhya MJN, Janeera B, Shaji SD et al. In-silico design, synthesis and in-vitro antidiabetic and anti-inflammatory activities of 1,3,4-thiadiazole substituted 2-methyl benzimidazole derivatives. JPRCP. 2016; 6(1): 27-38. 